\title{
In vitro susceptibility of Plasmodium falciparum Welch field isolates to infusions prepared from Artemisia annua $\mathrm{L}$. cultivated in the Brazilian Amazon
}

\author{
Luiz Francisco Rocha e Silva ${ }^{1,2,3}$, Pedro Melillo de Magalhães ${ }^{4}$, Mônica Regina Farias Costa ${ }^{5}$, \\ Maria das Graças Costa Alecrim ${ }^{5}$, Francisco Célio Maia Chaves ${ }^{6}$, Ari de Freitas Hidalgo ${ }^{7}$, \\ Adrian Martin Pohlit ${ }^{1 /+}$, Pedro Paulo Ribeiro Vieira ${ }^{2,5}$
}

\author{
'Laboratório de Princípios Ativos da Amazônia, Instituto Nacional de Pesquisas da Amazônia, Manaus, AM, Brasil \\ ${ }^{2}$ Universidade do Estado do Amazonas, Manaus, AM, Brasil ${ }^{3}$ Centro Universitário do Norte, Manaus, AM, Brasil \\ ${ }^{4}$ Universidade Estadual de Campinas, Paulínia, SP, Brasil ${ }^{5}$ Fundação de Medicina Tropical Heitor Vieira Dourado, Manaus, AM, Brasil \\ ${ }^{6}$ Embrapa Amazônia Ocidental, Manaus, AM, Brasil ${ }^{7}$ Universidade Federal do Amazonas, Manaus, AM, Brasil
}

\begin{abstract}
Artemisinin is the active antimalarial compound obtained from the leaves of Artemisia annua L. Artemisinin, and its semi-synthetic derivatives, are the main drugs used to treat multi-drug-resistant Plasmodium falciparum (one of the human malaria parasite species). The in vitro susceptibility of $\mathrm{P}$. falciparum $\mathrm{K} 1$ and $3 d 7$ strains and field isolates from the state of Amazonas, Brazil, to A. annua infusions (5 g dry leaves in $1 \mathrm{~L}$ of boiling water) and the drug standards chloroquine, quinine and artemisinin were evaluated. The A. annua used was cultivated in three Amazon ecosystems (várzea, terra preta de índio and terra firme) and in the city of Paulínia, state of São Paulo, Brazil. Artemisinin levels in the A. annua leaves used were $0.90-1.13 \%(\mathrm{~m} / \mathrm{m})$. The concentration of artemisinin in the infusions was 40-46 mg/L. Field P. falciparum isolates were resistant to chloroquine and sensitive to quinine and artemisinin. The average 50\% inhibition concentration values for A. annua infusions against field isolates were 0.11-0.14 $\mu \mathrm{L} / \mathrm{mL}$ (these infusions exhibited artemisinin concentrations of 4.7-5.6 $\mathrm{ng} / \mathrm{mL}$ ) and were active in vitro against $\mathrm{P}$. falciparum due to their artemisinin concentration. No synergistic effect was observed for artemisinin in the infusions.
\end{abstract}

Key words: Artemisia annua L. - infusion - antiplasmodial - in vitro - field isolate - Amazon Region

Malaria is an infectious disease that affects millions of people in tropical and sub-tropical regions of the world. According to the estimates of the World Health Organization (WHO), $40 \%$ of the world population, that is, 3.3 billion people, live at high risk of contracting this disease in the 106 countries where malaria is considered to be endemic. In 2009, 225 million cases of malaria were registered around the world and caused approximately one million deaths, of which $90 \%$ were among African children less than five years of age (WHO 2010). In the Brazilian Amazon, this disease is still a grave problem for public health authorities due to its high incidence and the debilitating effects on people suffering from this disease. This disease is believed to negatively influence the potential economic development of this region (OliveiraFerreira et al. 2010).

Resistance of the human malaria parasite Plasmodium falciparum Welch to antimalarial drugs has emerged as one of the greatest challenges to the control of malaria. Drug resistance has led to increased mortality in hyper

Financial support: MCT-CNPq/MS-SCTIE-DECIT (25/2006), MCTCNPq/PPG-7 (63892/2005-6)

LFRS received a scholarship from FAPEAM (RH-Interiorização).

+ Corresponding author: ampohlit@inpa.gov.br

Received 16 January 2012

Accepted 8 August 2012 and holoendemic areas and contributed to the appearance and spread of new focal areas of malaria caused by P. falciparum. Furthermore, resistance has been identified as a factor that economically compromises malaria control efforts (Trape et al. 2002). Great effort and time have been dedicated to the in vitro reproduction of the erythrocytic stages of the Plasmodium life cycle as a fundamental tool for studying the mechanisms of susceptibility and resistance to drugs as well as screening for the identification of new drugs (Girard et al. 2007).

Several natural products have been revealed as promising sources of antimalarial compounds. Traditional knowledge of the usefulness of medicinal plants has led to the isolation and identification of the antimalarial compounds quinine and artemisinin, which are currently in use and which are isolated from species of Cinchona L. (Rubiaceae) and the leaves of Artemisia annua L. (Asteraceae), respectively (Vale et al. 2005).

A. annua is a plant native to North China, mainly in the provinces of Chahar and Suiyuan, where it is known by the common name qinghao (blue-green hao) (Hsu 2006). This herb has been used in traditional Chinese medicine for more than 2,000 years as an infusion for the treatment of fever and malaria. The modern Chinese Pharmacopeia describes the dry leaves of this plant as a medicine for fever, including malaria (Mueller et al. 2000). Chinese researchers have studied more than 30 species belonging to the genus Artemisia in the search for potential antimalarial activity; however, only $A$. annua and Artemisia apiacea Hance have proven to be 
effective against $P$. falciparum and Plasmodium vivax Grassi \& Feletti (Rodrigues et al. 2006). Among the secondary metabolites present in $A$. аппиа, artemisinin is considered to be the principle antimalarial component. Artemisinin levels vary considerably depending upon the part of the plant, cultivation conditions and seasonal and geographical variations. High levels of artemisinin are found in the leaves and flowering parts, especially in the period immediately before flowering $(0.01-1.40 \%)$ (Baraldi et al. 2008). Most of this variation is attributed to genetic factors; however, even high-artemisininyielding varieties may have their artemisinin production reduced due to the influence of environmental conditions. Altitude, latitude, soil nutrients and $\mathrm{pH}$, the length of day (photoperiod), flowering time, drying time and storage conditions determine the artemisinin content in the plant (Wilcox et al. 2004, Ferreira et al. 2005).

The global demand for artemisinin and its derivatives increased from 11.2 million treatments in 2005 to approximately 158 million in 2009. The cost-benefit relationship represents the greatest problem for the viability of the synthesis of artemisinin. The isolation of artemisinin from the leaves of $A$. апnиa is the best method for obtaining artemisinin, from which semi-synthetic derivatives such as artesunate, artemether and arteether are prepared (WHO 2010). Given the possible decrease in the supply of artemisinin caused by this increase in world demand, the cultivation of $A$. апnиa, especially in endemic areas, may be an important alternative for the production of artemisinin-based drugs (Mueller et al. 2000). This plant was introduced in Brazil in the 1980's and has been the subject of constant study and attempts at genetic improvement through traditional methods. These studies resulted in the selection of high-artemisinin-yielding genotypes for cultivation in intertropical regions (Magalhães et al. 1997). Although trials with some of these genotypes have already been conducted in the Brazilian Amazon Region, it is necessary to perform multidisciplinary research on the genetic selection and improvement of $A$. аппиа for cultivation in distinct Amazon ecosystems.

Infusion is the pharmaceutical form indicated in the Chinese Pharmacopeia for $A$. апnиa and is the most commonly used form today. The recommended dose varies from 4-9 $\mathrm{g}$ of dried leaves for each litre of boiling water (Ridder et al. 2008). In the most important clinical studies reported in the literature involving infusions of $A$. аппиа, 5-9 g of dry plant per litre of boiling water per day for five-seven days has been the usual course of treatment. In clinical studies, the therapeutic efficiency of A. апnиа infusions was up to $70 \%$, but high recrudescence rates were reported, which led the authors of these clinical studies to not recommend the use of $A$. annua infusions as a monotherapy (Mueller et al. 2000, 2004, Räth et al. 2004).

At present, $A$. annua is being cultivated in Amazon ecosystems through the Artemisia Project, which is being financed by a grant from the Brazilian Government's National Malaria Network. The evaluation of the quality of these hybrids has been performed by monitoring biomass during the plant's life cycle, as well as the evaluation of artemisinin levels in the leaves. In the present study, the susceptibility of field isolates of P. falciparum from the Brazilian Amazon to A. апnиa infusions was evaluated. The $A$. annua used in this study was cultivated in the várzea, terra firme and terra preta de indio ecosystems. An attempt was made to understand the interaction between the parasites and the infusions and ultimately to establish the antiplasmodial activity of the infusions against $P$. falciparum in vitro as a parameter in the evaluation of the potency of cultivated A. апnи a and the infusions made from the cultivated plant.

\section{SUBJECTS, MATERIALS AND METHODS}

Plant material - The A. annua L. used in this study was grown from seed in greenhouses and then cultivated in várzea, terra firme and terra preta de índio Amazonian ecosystems in the experimental areas of the Brazilian Agriculture and Animal Husbandry Research Company (Embrapa) in Manaus, state of Amazonas, Brazil. Plant collection was performed in June 2008 from these three Amazonian ecosystems. A hybrid of $A$. annua from the Multidisciplinary Centre for Chemical, Biological and Agricultural Research (CPQBA) of the State University of Campinas (UNICAMP), Paulínia, state of São Paulo, Brazil, was also used for reference and was collected in March 2008. Reference plant materials (vouchers) are available at CPQBA and Embrapa and live plant specimens are maintained in continuous culture on a yearly basis at these institutions. For this study, the aerial parts of the plants were harvested immediately before flowering commenced and dried in an oven at $40^{\circ} \mathrm{C}$.

Preparation of leaf infusions - Infusions of $A$. апnиа leaves from plants grown in terra firme, várzea and terra preta de indio areas at Embrapa in Manaus and at CPQBA in Paulínia were prepared by combining $5.0 \mathrm{~g}$ of dry, ground leaves and $1.0 \mathrm{~L}$ boiling distilled water. The mixture was covered and left for $15 \mathrm{~min}$ and then filtered hot.

Preparation of leaf extracts for quantification of artemisinin - Toluene $(10.0 \mathrm{~mL})$ was added to dried leaves $(200 \mathrm{mg}$ ) and this mixture was subjected to extraction in an Ultra-Turrax homogeniser (IKA, Guankzhou, China) for $30 \mathrm{~s}$. The resulting suspension was centrifuged for 6 $\mathrm{min}$ at 3,200 $\mathrm{rpm}(1,720 \mathrm{~g})$. The supernatant solution was used in the analyses as described below.

Determination of artemisinin in toluene solutions and infusions of A. annua leaves - Artemisinin levels were determined in $\operatorname{dry} A$. апnиa leaf samples and infusions using thin-layer chromatography (TLC)-photodensitometry as previously described (Marchese et al. 2001) with slight modifications. After the centrifugation step described above, the supernatant toluene solution $(3.0 \mu \mathrm{L})$ was applied in duplicate to a commercial aluminium-backed silica gel TLC plate (Merck). On the same plate, four different volumes (1.5-3.0 $\mu \mathrm{L})$ of a standard solution of artemisinin $(0.25 \mathrm{mg} / \mathrm{mL})$ in methanol were applied to the TLC plate as calibration points. The TLC plate was eluted with a 98.5:1.5 mixture of chloroform and methanol. The average elution times were $4 \pm 1 \mathrm{~min}$. The eluted TLC plate was sprayed with $p$-anisaldehyde solution [0.5 mL $p$-methoxybenzaldehyde, $10 \mathrm{~mL}$ glacial acetic acid, $85 \mathrm{~mL}$ ethanol and $5 \mathrm{~mL}$ concentrated sulphuric acid (95-97\%)] and heated for $6 \mathrm{~min}$ at $100^{\circ} \mathrm{C}$. 
Next, the TLC plate was scanned using a photodensitometer (GE Healthcare Image Scanner ${ }^{\circledR}$ ). The optical densities of the artemisinin spots in the toluene solutions were compared to the optical densities of the standard samples of artemisinin (external calibration) using GE Image Quant TL ${ }^{\circledR}$ software (GE Healthcare, Uppsala, Sweden). To quantify artemisinin in the infusions, $100 \mathrm{~mL}$ of each infusion was totally evaporated under vacuum ( $c a$. $25 \mathrm{mmHg}$ ) using a rotary evaporator and a bath temperature of $38^{\circ} \mathrm{C}$. The resulting dry extract was suspended in $10.0 \mathrm{~mL}$ of methanol, which was measured using a volumetric pipette. A total of $3.0 \mu \mathrm{L}$ of this suspension was applied to a TLC plate using a gas-tight microsyringe and evaluated as described above for toluene solutions.

Continuous culture of P. falciparum - The strains used in this study were the antimalarial drug-susceptible 3D7 clone of the NF54 isolate (unknown origin) and the chloroquine-resistant, pyrimethamine-resistant and cycloguanil-resistant K1 strain (Thailand). Strains were acquired from MR4 (Malaria Research and Reference Reagent Resource Center, Manassas, VA, USA). Additionally, nine $P$. falciparum field isolates (representative genotypes from the Brazilian Amazon Region) were obtained from symptomatic malaria patients who presented themselves for diagnosis and treatment at the Heitor Vieira Dourado Tropical Medicine Foundation (FMTHVD), Manaus. Whole blood samples were processed as described elsewhere (Vieira et al. 2004) and infected erythrocytes were directly added to complete RPMI-medium and put in plastic flasks for in vitro culture (without cryopreservation) under a low-oxygen atmosphere. Patients presenting clinical symptoms related to severe malaria were invited to be enrolled in this study after confirmation of $P$. falciparum mono infection by thick smear diagnosis and their signing of an informed consent form (FMT-HVD Ethics in Research Commission 1838). Parasites were maintained in continuous culture using the method of Träger and Jensen (1976) with modifications, as described in Andrade-Neto et al. (2007), using type $\mathrm{A}^{+}$ human erythrocytes in RPMI-1640 medium (Sigma-Aldrich, St. Louis, MO, USA) supplemented with $10 \% \mathrm{~A}^{+}$ human plasma (donated by blood banks). Cultures were maintained under an environment of $5 \% \mathrm{O}_{2}, 5 \% \mathrm{CO}_{2}$ and $90 \% \mathrm{~N}_{2}$ and incubated at $37^{\circ} \mathrm{C}$. When cultures attained a parasitaemia level of $4-5 \%$, they were synchronised with 5\% sorbitol (Lambros \& Vanderberg 1979).

In vitro susceptibility test - Infusions of A. annua, as prepared above, were diluted by a factor of 1:10 and then serially diluted in RPMI-1640 culture medium by a factor of 1:5 to produce seven diluted samples with overall dilutions that ranged from 1:10-1:1.5 $\times 10^{5}$. These dilute samples were tested in vitro against field isolates and standard strains of P. falciparum. The commercial drug standards chloroquine diphosphate salt (Sigma-Aldrich, Steinheim, Westphalia, Germany), quinine sulphate salt (Sigma-Aldrich, Steinheim, Westphalia, Germany) and artemisinin (Sigma-Aldrich, Steinheim, Westphalia, Germany) were also tested in the concentration ranges of 2.5 $\times 10^{3}-3.4,5.0 \times 10^{2}-0.70$ and $1.0 \times 10^{2}-6.4 \times 10^{-3} \mathrm{ng} / \mathrm{mL}$, respectively. The microtest was performed according to the method of Rieckmann et al. (1978) with modifications as described in Andrade-Neto et al. (2007). Briefly, the wells of a 96-well test plate were loaded with $180 \mu \mathrm{L}$ of a parasitised red blood cell suspension in culture medium containing predominantly young trophozoites (ring forms), a $3 \%$ haematocrit and $1.5 \%$ initial parasitaemia. Then, $20 \mu \mathrm{L}$ of a commercial drug solution or a dilute infusion was added to wells for a final volume of $200 \mu \mathrm{L}$ per well. Each test was performed in triplicate. Wells containing only parasitised red blood cells in complete culture medium (RPMI-1640 plus 10\% human serum) were used as negative controls of parasite growth. Each test plate was incubated for $48 \mathrm{~h}$ at $37^{\circ} \mathrm{C}$ and at low $\mathrm{O}_{2}$ tension in an acrylic, gas-tight chamber in an incubator. After incubation, thin blood smears were prepared from the contents of each well. Blood smears were dyed with Panótico ${ }^{\circledR}$ (Laborclin, Pinhais, Paraná, Brazil) and examined under an optical microscope. The number of parasites present in a total of 2,000 red blood cells was counted. Parasitaemia levels were expressed as a percentage.

Data analysis - The parasitaemia levels of the test wells were compared with those of the control wells to evaluate parasite growth in the presence of diluted $A$. апnиа infusion or drug standards. The inhibition of parasite growth was evaluated as the difference in the average level of parasitaemia of triplicate negative control wells and the average parasitaemia level of the triplicate wells of a given test sample and was expressed as a percentage (I\%) by dividing this difference by the average negative control parasitaemia level $[\mathrm{I} \%=(\mathrm{avg}$ parasitaemia of control - avg parasitaemia of sample) $\div$ avg parasitaemia of control]. The median inhibition concentration $\left(\mathrm{IC}_{50}\right)$ and the standard deviation with a $95 \%$ confidence interval were calculated based on linear regression analysis using Microcal Origin ${ }^{\circledR}$ software (OriginLab, Northampton, Massachusetts, USA).

\section{RESULTS}

The dried leaves of $A$. annua hybrids cultivated in the várzea, terra preta de indio and terra firme Amazonian ecosystems exhibited high levels of the antimalarial natural product artemisinin. The results from our TLC-photodensitometric analysis indicate that artemisinin levels in dry leaves ranged from $0.90 \pm 0.10 \%-1.10$ $\pm 0.07 \%$ (Table I). The dry leaves of the standardised plant cultivated in Paulínia exhibited artemisinin levels of $1.13 \pm 0.05 \%$. The seeds were obtained from these standardised plants, which in turn gave rise to the plants cultivated in the Amazon.

The concentration of artemisinin in infusions of leaves of cultivated $A$. аnnиa ranged from $40-46 \mathrm{mg} / \mathrm{L}$ (Table I). Thus, we did not observe a large variation in the concentration of artemisinin in the infusions. Standardised A. annua cultivated in Paulínia exhibited higher levels of artemisinin in its leaves and in its leaf infusions. The efficiency of artemisinin extraction by the infusion of leaves in boiling water ranged from $78-91 \%$ for plants cultivated in terra preta de indio and terra firme plots. The efficiency of extraction described here refers to the percentage of the total artemisinin present in the leaf sample that was present in the final infusions. 
The drug sensitivity profiles of the nine $P$. falciparum field isolates were evaluated against the commercial drugs chloroquine, quinine and artemisinin through the determination of their $\mathrm{IC}_{50}$ values (Table II). For chloroquine, the average $\mathrm{IC}_{50}$ value for the nine field isolates was $268 \pm 129 \mathrm{nM}$. The lowest of the $\mathrm{IC}_{50}$ values for these parasites was $166 \mathrm{nM}$. Thus, all field isolates were considered resistant to chloroquine (WHO 2007). For quinine, the average $\mathrm{IC}_{50}$ value for the nine field isolates was $174 \pm 40 \mathrm{nM}$ (the absolute range of $\mathrm{IC}_{50}$ values was $110-259 \mathrm{nM}$ ), as shown in Table II. All $P$. falciparum field isolates were considered sensitive to quinine because their $\mathrm{IC}_{50}$ values were lower than the in vitro threshold values $\left(\mathrm{IC}_{50}=500 \mathrm{nM}\right)$ for quinine resistance established by the WHO (2007). Artemisinin was highly active against Amazonian field isolates of $P$. falciparum. The $\mathrm{IC}_{50}$ values obtained for artemisinin against Amazonian field isolates exhibited low variation (average $\mathrm{IC}_{50}=2.1 \pm 1.0 \mathrm{nM}$ ). Given the number of samples studied, the levels of sensitivity of Amazonian $P$. falciparum field isolates to artemisinin are in agreement with results for other field isolates reported

TABLE I

Data on artemisinin in leaves and infusions

\begin{tabular}{|c|c|c|c|}
\hline Plant origin & $\begin{array}{l}\text { Artemisinin } \\
\text { in dry leaves } \\
\qquad(\mathrm{m} / \mathrm{m})\end{array}$ & $\begin{array}{l}\text { Concentration of } \\
\text { artemisinin } \\
\text { in infusions } \\
(\mathrm{mg} / \mathrm{L})\end{array}$ & $\begin{array}{c}\text { Efficiency of } \\
\text { extraction }^{a}\end{array}$ \\
\hline Paulínia & $1.13 \pm 0.05$ & $46 \pm 2$ & 81 \\
\hline Terra preta & $1.10 \pm 0.07$ & $43 \pm 1$ & 78 \\
\hline Terra firme & $0.90 \pm 0.10$ & $41 \pm 2$ & 91 \\
\hline Várzea & $0.90 \pm 0.10$ & $40 \pm 1$ & 90 \\
\hline
\end{tabular}

$a$ : percentage of artemisinin extracted from leaves into tea preparation. Artemisinin levels in dry leaves and infusions prepared from Artemisia annua cultivated in three Amazonian ecosystems (Manaus, state of Amazonas) and Paulínia (state of São Paulo) and artemisinin extraction efficiency of infusion procedure. in the literature (Jambou et al. 2005, Ferreira et al. 2007, 2008, Gama et al. 2011). In Fig. 1, concentration-response curves are presented for the largest and smallest inhibition concentrations obtained for field isolates against chloroquine, quinine and artemisinin. These curves are generally representative of the experimental observations made on the rest of the field isolates.

The susceptibilities of 11 samples of $P$. falciparum (2 standard and 9 field isolated samples) to infusions of A. annua leaves from three Amazonian ecosystems and Paulínia were evaluated herein. Immediately after preparation, each infusion was diluted and applied directly to the microtest plate without any prior treatment. $\mathrm{The}_{\mathrm{IC}}$ values were calculated in experimentally relevant units of microlitres of infusion per millilitre $(\mu \mathrm{L} / \mathrm{mL})$ of total solution in each microplate well. The average $\mathrm{IC}_{50}$ values of the $A$. апnиa leaf infusions against samples of $P$. falciparum were $0.11 \pm 0.03,0.11 \pm 0.02,0.13 \pm 0.1$ and $0.14 \pm 0.04 \mu \mathrm{L} / \mathrm{mL}$ for plants cultivated in Paulínia, terra preta de indio, terra firme and várzea, respectively. If the data from the TLC-photodensitometric analysis of the infusions are taken into account, these diluted infusions that produced the $\mathrm{IC}_{50}$ values contain 5.1, 4.7, 5.3 and $5.6 \mathrm{ng} / \mathrm{mL}$ of artemisinin, respectively. There was no significant difference in the $\mathrm{IC}_{50}$ values of plant infusions from different regions/ecosystems against individual field isolates of P. falciparum. Similarly, there was no significant difference in the susceptibility profiles among the field isolates to individual infusions. In Fig. 2 , the concentration-response curves are presented for a field isolate against different infusions of $A$. аппиа. In general, these curves are representative of the behaviour profile of field isolates of $P$. falciparum in the presence of $A$. апnиa infusions. The biological responses of this field isolate to the leaf infusions of plants cultivated in terra firme and várzea areas were slightly delayed, which resulted in higher $\mathrm{IC}_{50}$ values.

\section{DISCUSSION}

The great importance attributed to $A$. аnnиa after the discovery of the highly active antimalarial compound in the leaves of this plant led to the intensive collection and decimation of the plant in certain regions of the world.

TABLE II

Antiplasmodial activity of drugs

\begin{tabular}{|c|c|c|c|c|}
\hline \multirow[b]{3}{*}{ Drug } & \multicolumn{4}{|c|}{ Median inhibition concentrations $\left(\mathrm{IC}_{50}\right)(\mathrm{nM})$} \\
\hline & \multicolumn{2}{|c|}{ Amazon field isolates } & \multicolumn{2}{|c|}{ Standard strains } \\
\hline & $\begin{array}{l}\text { Mean } \\
(\mathrm{n}=9)\end{array}$ & Lowest/highest & K1 & $3 \mathrm{D} 7$ \\
\hline Chloroquine diphosphate & 268 & $166 / 460$ & $136 \pm 10$ & $60 \pm 6$ \\
\hline Quinine sulphate & 174 & $110 / 259$ & $160 \pm 8$ & $110 \pm 10$ \\
\hline Artemisinin & 2.1 & $0.9 / 3.5$ & $2.9 \pm 1$ & $1.7 \pm 1$ \\
\hline
\end{tabular}

$\overline{\mathrm{IC}_{50} \text { values for commercial drugs chloroquine, quinine and artemisinin against standard strains and Amazonian field isolates of }}$ Plasmodium falciparum. 
As a response to the high demand for this plant, A. annua has been planted on a large scale in China, Vietnam, Turkey, Iran, Afghanistan and Australia, as well as some countries in Europe and the Americas (Bhakuni et al. 2001). Faced with a possible shortage in the supply of artemisinin caused by the increase in demand, the cultivation of A. апnиа in endemic areas should be considered a viable alternative that will guarantee an adequate supply of plant materials and production of the drug artemisinin (Ridder et al. 2008). The present study demonstrated that A. annua cultivated in three types of representative soils of the Amazon Region possesses a high level of artemisinin. This finding, together with agronomic and biomass data, support the notion that $A$. апnиа can be cultivated

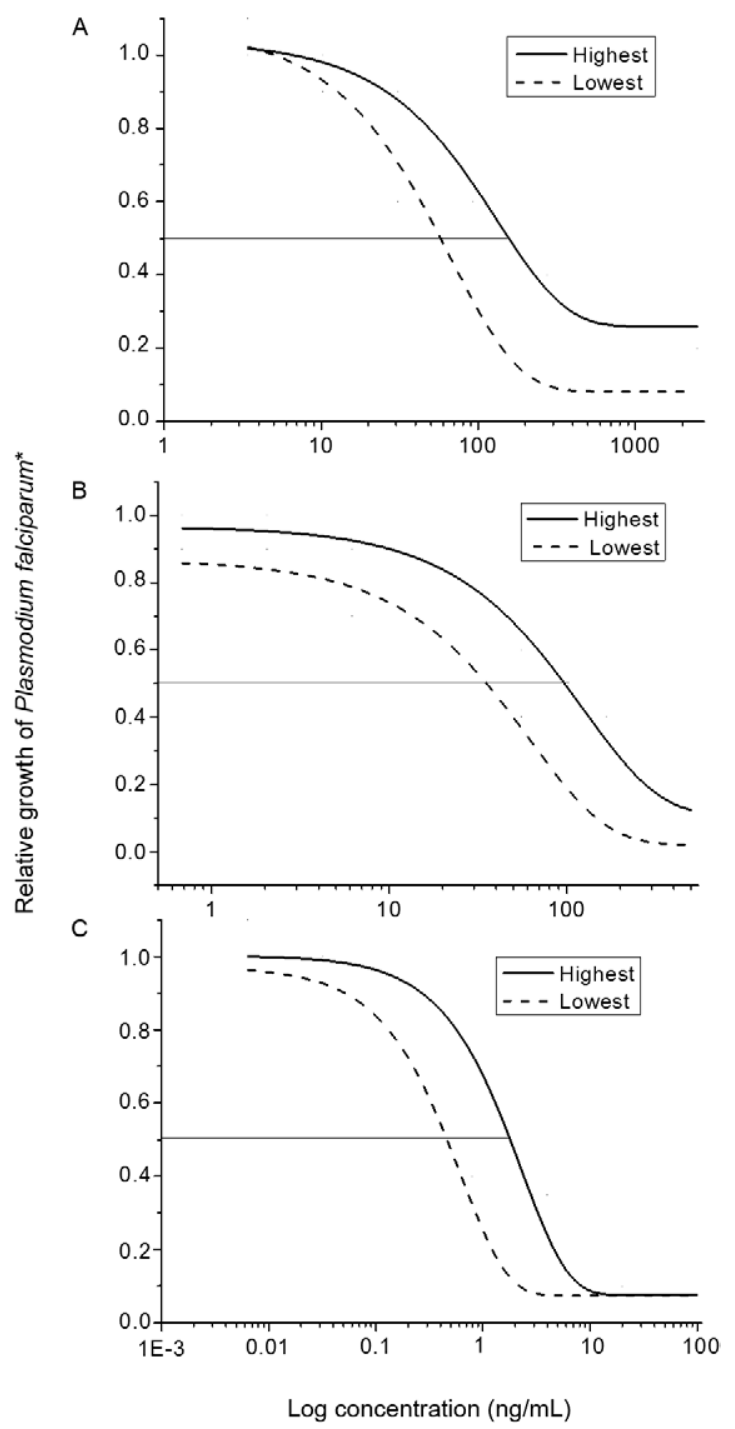

Fig. 1: concentration-response curves for field isolates of $P$. falciparum in the presence of various concentrations of commercial drug standards (A: chloroquine; B: quinine; C: artemisinin) (lowest and highest $\mathrm{IC}_{50}$ values). Asterisk means relative growth of $P$. falciparum $=$ avg $\%$ parasitaemia of test (sample) wells/avg \% parasitaemia of untreated control wells ( $95 \%$ confidence interval). Statistical analysis among additional assays: standard error $=0.0007 ; \mathrm{p}=0.10$. in this rainy, humid equatorial region. The $A$. annua hybrid cultivated in Paulínia (UNICAMP/CPQBA) is considered stable because it has been cultivated for many generations and has had its ideal growth conditions established for some time. Previous studies have reported that leaves of this hybrid have artemisinin levels in the range 0.8-1.2\% (Magalhães et al. 1997, Marchese et al. 2001). No large variation in the levels of artemisinin among the hybrids in the three Amazonian ecosystems was observed despite the rather large differences in the nutritional composition of soils of the várzea, terra preta de indio and terra firme areas (Sanchez et al. 1982). The levels of artemisinin found in these hybrids cultivated in the Amazon are similar to those found in the standardised and stabilised plants from Paulínia from which the Amazon hybrids are derived. The plants used in this study are the result of the first generation of $A$. апnиа cultivated in these Amazonian soils and these plants are still going through a process of adaptation to the climatic and geologic conditions of the Amazon Region.

The method used to determine the levels of artemisinin in the dry leaves and infusions prepared from these leaves is semi-quantitative and is based on TLC-photodensitometry, which has a high correlation with the method of choice, namely, high-performance liquid chromatography (Marchese et al. 2001). TLC-photodensitometry is rapid because 3-4 samples and calibration samples are simultaneously eluted and quantified by the software, which has as its input the high-resolution scan of the eluted TLC plate. Furthermore, TLC-photodensitometry is very low cost and is highly adaptable to field conditions, where it is useful in the processing of a large number samples during the process of plant selection for genetic improvements. This method was also used to measure artemisinin levels in previous studies that evaluated the biological activity of A. апnиa infusions (Atemnkeng et al. 2009).

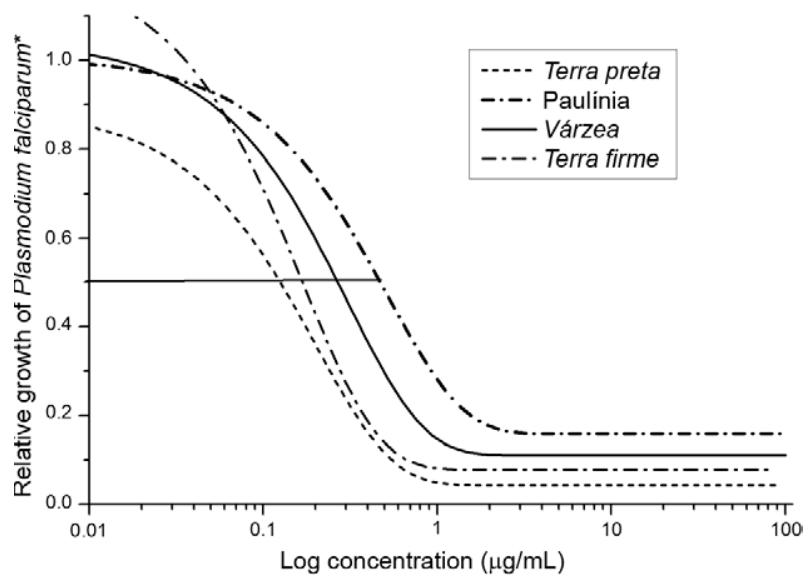

Fig. 2: concentration-response curves for a field isolate of $P$. falciparum in the presence of various concentrations of infusions of $\mathrm{Ar}$ temisia апnиa from different ecosystems/regions. Asterisk means relative growth of $P$. falciparum $=$ avg $\%$ parasitaemia of test (sample) wells/avg \% parasitaemia of untreated control wells ( $95 \%$ confidence interval). Statistical analysis among additional assays: standard error $=0.0006 ; \mathrm{p}=0.10$. 
Pure artemisinin has poor solubility in water and, as was shown above, infusions of the dry leaves of $A$. annua prepared as recommended in the Chinese Pharmacopeia contain a substantial quantity of artemisinin (Table I). These findings are similar to those found by Räth et al. (2004), who performed a pharmacokinetic study utilising an infusion of $A$. апnиа to determine the plasma concentration of artemisinin after the oral administration of the infusion. In the study by Räth et al. (2004), the leaf infusion was prepared in a way that was analogous to that used in the present study starting from dry leaves with $1.39 \%$ artemisinin and yielding infusions with $57.5 \mathrm{mg}$ artemisinin/L. Atemnkeng et al. (2009) used this procedure to prepare infusions containing $34 \mathrm{mg}$ artemisinin/L from dry leaves that contained $1.12 \%$ artemisinin. Despite the low solubility of artemisinin in water, the large quantities of the drug in infusions is believed to be due to the presence of other extracted constituents of the plant that have amphiphilic properties (e.g., flavonoids and/or saponins), which increase the solubility of artemisinin in water (Ridder et al. 2008).

During the adaptation of medicinal plants to new climatic and geologic conditions, it is important to accompany the process with techniques that will guarantee the quality of the plant material obtained, such as the monitoring of the levels of active compounds which is a common practice. For the quality control of cultivated $A$. annua, the determination of artemisinin levels in the leaves is crucial (Celeghini et al. 2006). In the present study, the quality of the A. annua hybrids cultivated in the Brazilian Amazon was monitored to establish artemisinin levels in the leaves through extraction with the low-polarity solvent toluene. The leaves of the hybrids cultivated in the Amazonian ecosystems contained acceptable levels of artemisinin: however, the standardised $A$. аnпиa hybrids from CPQBA (Paulínia) had the highest levels of artemisinin. The quality of the infusions prepared from the leaves of the Amazonian hybrids was also monitored and compared with the standardised plant from Paulínia through the levels of artemisinin in the infusions and by testing these infusions for antimalarial activity against $P$. falciparum in vitro. There are reports in the literature on the in vivo antimalarial activity, pharmacology, efficacy and safety of $A$. annua infusions in human clinical trials (Mueller et al. 2000, 2004, Räth et al. 2004) and in vivo in animals using rodent malaria parasite-based models (Atemnkeng et al. 2009). However, we could find no previous report on the in vitro antiplasmodial activity of $A$. annua infusions. In a recent study, the cytotoxicity of $A$. annua infusions was assessed by determining cellular viability using the (2-methoxy-4-nitro-5-sulphophenyl)$2 \mathrm{H}$-tetrazolium-5-carboxanilide assay. In that study, the viability of cells in the presence of different concentrations of $A$. аnпиа infusion was above $72 \%$ even when the highest concentrations were tested (Oliveira et al. 2009). These data are consistent with the generally low cytotoxicity of $A$. annua infusions.

The stabilisation of geographically specific populations of $P$. falciparum in continuous culture permits the evaluation of the actual susceptibility profiles to drugs and to natural products of the parasites that are in circulation in the human (and insect) populations in a given region (Andrade-Neto et al. 2007). In the present study, it was possible to stabilise, in continuous culture, nine $(16 \%)$ of 55 field isolates of P. falciparum. The increase in the therapeutic failure rates of many antimalarial drugs in most malarious regions requires epidemiologic monitoring and monitoring of the dynamics of drug resistance. Information on the epidemiology of resistance can be applied to the monitoring and control of the appearance and propagation of chemoresistance in populations of natural parasites. This monitoring can be performed with drugs in use in a particular location or with new drug alternatives, especially when the parasite exhibits cross-resistance to drugs (Ferreira et al. 2007, Chiyaka et al. 2009). The stabilised field isolates developed and examined in the present study exhibited similar sensitivity profiles to chloroquine, quinine and artemisinin. The resistance of Amazonian $P$. falciparum to chloroquine in vitro was expected given that this parasite is generally known to be resistant to this drug throughout the Amazon and many other parts of the world. In general, chloroquine is no longer recommended for the treatment of $P$. falciparum infections due to the high levels of resistance observed in the clinical setting (WHO 2005). Although there are reports on the in vivo and in vitro resistance to quinine in the Amazon Region (Alecrim 1981), in the present work resistance to quinine was not detected. However, two samples revealed high $\mathrm{IC}_{50}$ values $(224$ and $259 \mathrm{nM}$ ) that were lower than the in vitro threshold value for quinine resistance $(500 \mathrm{nM})$ established by the WHO (2007). The levels of field isolate parasite inhibition $\left(\mathrm{IC}_{50}=2.1\right.$ $\pm 1.0 \mathrm{nM}$ ) by artemisinin are generally in agreement with data from other parts of South America and Brazil (Jambou et al. 2005, Ferreira et al. 2007, 2008). The drug susceptibility of field isolates was evaluated as a means to characterise the resistance profiles of the samples of Amazonian parasites utilised to evaluate their susceptibility to infusions.

The samples of $P$. falciparum evaluated in this study exhibited a high degree of susceptibility to infusions prepared from the dry leaves of $A$. annua cultivated in all ecosystems. Even highly dilute infusions (1:6.2 $\times$ $10^{3}$; effective concentrations of artemisinin of $c a .6 .4$ $\mathrm{ng} / \mathrm{mL}$ ) inhibited up to $100 \%$ of parasite growth in almost all of the field isolates (data not shown). The $\mathrm{IC}_{50}$ values of the infusions were as low as $0.11 \pm 0.02 \mu \mathrm{L} /$ $\mathrm{mL}$. Based on our TLC-photodensitometry studies, this value corresponds to an effective artemisinin concentration in the experimental test wells of $4.7 \mathrm{ng} / \mathrm{mL}$. These $\mathrm{IC}_{50}$ values were observed for infusions prepared from the leaves of $A$. annua cultivated in the terra preta ecosystem. $\mathrm{IC}_{50}$ values obtained in the in vitro tests involving infusions were comparable (Table III). Similar levels of artemisinin in the A. апnи a plants cultivated in the different soils of the Amazon and Paulínia (Table I) were found. Also, similar concentrations of artemisinin were detected in the infusions prepared from the leaves 
of A. апnиа. In addition, pure artemisinin was generally quite active in vitro against all parasites used in this study, as evidenced by the $\mathrm{IC}_{50}$ values (Table II). It is important to develop high-artemisinin-yielding genotypes of $A$. апnиa, especially in endemic areas, where such plants may be a means by which to guarantee a constant supply of plant material for artemisinin production. However, according to previous in vitro studies on the active components of $A$. annua against $P$. falciparum, artemisinin is not the only active substance present in the plant. It has been demonstrated previously that flavonoids present in A. апnиа are also involved in the in vitro antiplasmodial effect of artemisinin. These flavonoids have little antiplasmodial activity themselves, but are capable of acting in synergy with artemisinin (Willcox et al. 2004, Bilia et al. 2006). This result indicates that the evaluation of the in vitro antiplasmodial activity of infusions prepared from plants whose adaptation is underway can be an important tool to monitor and guarantee the activity and stability of $A$. апnиa. It is noteworthy that in the data generated herein, there was no evidence for in vitro synergistic effects.

As stated above, the plants in the present study are first-generation $A$. апnиa cultivated in the Amazon. Despite the relatively high yield of artemisinin detected in leaves and the high antiplasmodial activity detected in the in vitro assay (as evidenced by the low $\mathrm{IC}_{50}$ values of all infusions against all P. falciparum strains tested), these plants require agronomic improvement through selection to increase biomass and genetic homogeneity for growth in the Amazonian ecosystems. In vitro testing for antiplasmodial activity is an important tool for quality control because the inhibition of $P$. falciparum by $A$. апnиa infusions is related, in general, to high levels of artemisinin and other antimalarial components to which these parasites are sensitive.

TABLE III

Antiplasmodial activity of Artemisia annua infusions

Median inhibition concentrations $\left(\mathrm{IC}_{50}\right)(\mu \mathrm{L} / \mathrm{mL})$

Field isolates $\quad$ Standard strains

\begin{tabular}{lccccc}
\cline { 2 - 3 } $\begin{array}{l}\text { Origin of } \\
\text { A. annua }\end{array}$ & $\begin{array}{c}\mathrm{Mean}^{a} \\
(\mathrm{n}=9)\end{array}$ & Lowest/highest & $\mathrm{K} 1$ & 3D7 \\
\hline Paulínia & $0.11(5.1)$ & $0.08 / 0.18$ & & 0.09 & 0.10 \\
Terra preta & $0.11(4.7)$ & $0.08 / 0.15$ & & 0.10 & 0.09 \\
Terra firme & $0.13(5.3)$ & $0.07 / 0.36$ & & 0.08 & 0.11 \\
Várzea & $0.14(5.6)$ & $0.09 / 0.20$ & 0.10 & 0.13 \\
\hline
\end{tabular}

$a$ : in parentheses are the $\mathrm{IC}_{50}$ values if one assumes only artemisinin as the active component, based on TLC-photodensitometry results (Table I). $\mathrm{IC}_{50}$ values of infusions prepared from the leaves of $A$. annua from three Amazonian ecosystems (Manaus, state of Amazonas) and Paulínia (state of São Paulo) against standard strains and isolated field samples of Plasmodium falciparum from the Brazilian Amazon.

\section{ACKNOWLEDGEMENTS}

To Michele Rodrigues, Walldelice Holanda Salgado and Ana Lúcia Silva, for technical support provided during the in vitro culturing and antimalarial testing procedures.

\section{REFERENCES}

Alecrim MGC 1981. Estudo da resistência do P. falciparum às drogas antimaláricas in vivo $e$ in vitro na Amazônia, MSc Thesis, Universidade de Brasília, Brasília, 116 pp.

Andrade-Neto VF, Pohlit AM, Pinto ACS, Silva ECC, Nogueira KL, Melo MRS, Henrique MC, Amorim RCN, Silva LFR, Costa MRF, Nunomura RCS, Nunomura SM, Alecrim WD, Alecrim MGC, Chaves FCM, Vieira PPR 2007. In vitro inhibition of Plasmodium falciparum by substances isolated from Amazonian antimalarial plants. Mem Inst Oswaldo Cruz 102: 359-365.

Atemnkeng AM, Chimanuka B, Dejaegher B, Heyden YV, PlaizierVercammen J 2009. Evaluation of Artemisia annua infusion efficacy for the treatment of malaria in Plasmodium chabaudi chabaudi infected mice. Exp Parasitol 122: 344-348.

Baraldi R, Isacchi B, Predieri S, Marconi G, Vinvieri FF, Bilia AR 2008. Distribution of artemisinin and bioactive flavonoids from A. annua during plant growth. Biochem System Ecol 36: 340-348.

Bhakuni RS, Jain DC, Sharma RP, Kumar S 2001. Secondary metabolites of Artemisia annua and their biological activity. Curr Sci 80: 35-48.

Bilia AR, Melillo de Magalhães P, Bergonzi MC, Vincieri FF 2006. Simultaneous analysis of artemisinin and flavonoids of several extracts of Artemisia annua L. obtained from a commercial sample and a selected cultivar. Phytomedicine 13: 487-493.

Celeghini RMS, Silva AP, Sousa IMO, Foglio MAM 2006. Evaluation of Artemisia annua L. clean-up methods for artemisinin quantification by HPLC. Rev Bras Pl Med 8: 119-122.

Chiyaka C, Garira W, Dube S 2009. Effects of treatment and drug resistance on the transmission dynamics of malaria in endemic areas. Theor Popul Biol 75: 14-29.

Ferreira I, Martinelli A, Rodrigues L, do Carmo E, do Rosário V, Póvoa M, Cravo P 2008. Plasmodium falciparum from Pará state (Brazil) shows satisfactory in vitro response to artemisinin derivatives and absence of the S769N mutation in the SERCA-type PfATPase6. Trop Med Int Health 13: 199-207.

Ferreira ID, Lopes D, Martinelli A, Ferreira C, Rosário VE, Cravo P 2007. In vitro assessment of artesunate, artemether and amodiaquine susceptibility and molecular analysis of putative resistance associated mutations of Plasmodium falciparum from São Tomé and Príncipe. Trop Med Int Health 1: 353-362.

Ferreira JFS, Laughlin JC, Delabays N, Magalhaes PM 2005. Cultivation and genetics of Artemisia annua L. for increased production of the antimalarial artemisinin. Plant Genetic Resources 3: 206-229.

Gama BE, Lacerda MVG, Daniel-Ribeiro CT, Ferreira-da-Cruz MF 2011. Chemoresistance of Plasmodium falciparum and Plasmodium vivax parasites in Brazil: consequences on disease morbidity and control. Mem Inst Oswaldo Cruz 106 (Suppl.I): 159-166.

Girard MP, Reed Z, Friede M, Kieny MP 2007. A review of human vaccine research and development: malaria. Vaccine 25: 1567-1580.

Hsu E 2006. The history of qing hao in Chinese materia medica. Trans $R$ Soc Trop Med Hyg 100: 505-508.

Jambou R, Legrand E, Niang M, Khim N, Lim P, Volney B, Ekala MT, Bouchier C, Esterre P, Fandeur T, Mercereau-Puijalon O 2005. Resistance of Plasmodium falciparum field isolates to invitro artemether and point mutations of the SERCA-type PfATPase6. Lancet 366: 1960-1963. 
Lambros C, Vanderberg JP 1979. Synchronization of Plasmodium falciparum erythrocytic stages in culture. J Parasitol 65: 418-420.

Magalhães PM, Delabays N, Sartoratto A 1997. New hybrid lines of antimalarial species Artemisia аппиа L. guarantee its growth in Brazil. Cien Cult 49: 413-415.

Marchese JA, Rehder VLG, Sartoratto A 2001. Quantificação de artemisinina em $A$. аппиа - Uma comparação entre as técnicas de cromatografia em camada delgada com detecção densitométrica e cromatografia líquida de alta eficiência com detecção no ultravioleta. Rev Bras Pl Med 4: 81-87.

Mueller MS, Karhagomba IB, Hirt HM, Wernakor E, Li SM, Heide L 2000. The potential of Artemisia annиa L. as a locally produced remedy for malaria in the Tropics: agricultural, chemical and clinical aspects. J Ethnopharmacol 73: 487-493.

Mueller MS, Runyambo N, Wagner I, Borrmann S, Dietz K, Heide L 2004. Randomized controlled trial of a traditional preparation of Artemisia annua L. (Annual Wormwood) in the treatment of malaria. Trans R Soc Trop Med Hyg 98: 318-321.

Oliveira TC, Silva DAO, Rostkowska C, Béla SR, Ferro EAV, Mellilode-Magalhães P, Mineo JR 2009. Toxoplasma gondii: effects of Artemisia aпnиa L. on susceptibility to infection in experimental models in vitro and in vivo. Exp Parasitol 122: 233-241.

Oliveira-Ferreira J, Lacerda MV, Brasil P, Ladislau JL, Tauil PL, DanielRibeiro CT 2010. Malaria in Brazil: an overview. Malaria J 9: 115.

Räth K, Taxis K, Walz G, Gleiter CH, LI SM, Heide L 2004. Pharmacokinetic study of artemisinin after oral intake of a traditional preparation of Artemisia annua L. (Annual Wormwood). Am J Trop Med Hyg 770: 128-132.

Ridder S, Kooy F, Verpoorte R 2008. Artemisia annua as a self-reliant treatment for malaria in developing countries. J Ethnopharmacol 120: $302-314$.

Rieckmann KH, Vampbell GH, Sax LJ 1978. Drug sensitivity of $P$. falciparum, an "in vitro" microtechnique. Lancet 7: 22-23.
Rodrigues RAF, Foglio MA, Júnior SB, Santos AS, Rehder VLG 2006. Otimização do processo de extração e isolamento do antimalárico artemisinina a partir de Artemisia annua L. Quim Nova 29: 368-372.

Sanchez PA, Bandy DE, Villachia JH, Nicholaids JJ 1982. Amazon Basin soils: management for continuous crop production. Science 216: 821-827

Träger W, Jensen JB 1976. Human malaria parasites in continuous culture. Science 193: 673-75

Trape JF, Pison G, Spiegel A, Enel C 2002. Combating malaria in Africa. Trends Parasitol 18: 224-230.

Vale N, Moreira R, Gomes P 2005. Quimioterapia da malária um século no desenvolvimento de antimaláricos. Qui Nova 99: 57-69.

Vieira PP, Ferreira MU, Alecrim MG, Alecrim WD, da Silva LH, Sihuincha MM, Joy DA, Mu J, Su XZ, Zalis MG 2004. Pfcrt polymorphism and the spread of chloroquine resistance in Plasmodium falciparum populations across the Amazon Basin. J Infect Dis 190: 417-424.

WHO - World Health Organization 2005. World Malaria Report 2005. Available from: whqlibdoc.who.int/publications/2005/9241593199_ eng.pdf.

WHO - World Health Organization 2007. Field application of in vitro assays for the sensitivity of human malaria parasites to antimalarial drugs. Library Cataloguing-in-Publication Data. Available from: whqlibdoc.who.int/publications/2007/9789241595155_eng.pdf.

WHO - World Health Organization 2010. World Malaria Report 2010. Available from: who.int/malaria/world_malaria_report_2010/en/ index.html.

Willcox M, Bodeker G, Bourdy G, Dhingra V, Falquet J, Ferreira JFS, Graz B, Hirt HM, Hsu E, Magalhães PM, Damien P, Wright CW 2004. Artemisia апnиa as a traditional herbal antimalarial. In M Willcox (ed.), Traditional medicinal plants and malaria, CRC Press, Boca Ranton, p. 43-59. 